\title{
Effect of genotype $x$ environment interactions of grapevine hybrids characteristics
}

\author{
Dragan Nikolić ${ }^{1}$, Zorica Ranković-Vasić ${ }^{1}$, Aleksandar Petrović ${ }^{1}$, Ivana Radojević ${ }^{2}$, Tatjana Jovanović-Cvetković ${ }^{3}$, \\ and Branislava Sivčev ${ }^{1}$ \\ ${ }^{1}$ University of Belgrade, Faculty of Agriculture, Belgrade, Serbia \\ ${ }^{2}$ Centre of Viticulture and Eenology, Niš, Serbia \\ ${ }^{3}$ University of Banja Luka, Faculty of Agriculture, Banja Luka, Republika Srpska - BiH
}

\begin{abstract}
Research in this paper was performed at two different locations: Radmilovac and Vršac in Serbia. Four new interspecific hybrids (9846, 9896, 19574 and 20506) which are intended for table consumption were used as a material. Grape yield per unit area, the properties of the bunch (bunch weight, bunch length, bunch width and number of berries in bunch), the properties of berry (berry weight, berry length and berry width), as well as the characteristic of grape quality (sugar content and total acids in the must) were studied in selected hybrids.

The highest yield per unit area in the localities Radmilovac and Vršac had a hybrid 9896 (14 998 kg/ha; 11 $365 \mathrm{~kg} / \mathrm{ha}$ ). Analysis of variance results showed for the bunch weight, bunch width and number of berries in bunch, berry weight and berry length significant differences among the genotypes. Significant differences between investigated localities were determined for the bunch length and all the berry characters. The interaction between genotype and localities showed significant differences for bunch length, berry length and berry width.

Since the genotypes in the initial yielding (third year after planting), they are showed satisfactory results in relation to the objectives of selection.
\end{abstract}

\section{Introduction}

Grapevine (Vitis vinifera L.) is of great economic importance in worldwide [15]. It is a very divergent species from the genetic standpoint. Since its distribution range is very wide, and its cultivation history very long, over time, a rich genetic diversity has arisen within the species. The differences arising from genetic modifications due to adaptations to various environmental conditions or crossings (spontaneous or anthropogenic) have resulted in the emergence of numerous cultivars [4]. Cultivars are differ from each other according to the morphological and physiological characteristics as well as economic and technological properties. The approximate number of different cultivars and germplasm collections held is 10,000 [14].

Serbia has very favorable agro-ecological conditions for growing a large number of grapevine cultivars, from early to very late table cultivars and wine cultivars. Grapevine has been grow in Serbia at about 25,000 ha. Wine cultivars are represented at about $75.7 \%$, and cultivars which grape is intended for consumption in the fresh state are grown at about $24.3 \%$ of the total area [2].

It is well known that grape production depends on cultivar selection. Thus, breeding could improve the cultivar genetic potentials [5]. Today, interspecies hybridization is the most important and most widespread method for creating new grapevine cultivars in many breeding programs in the world $[1,7]$.
The Faculty of Agriculture in Belgrade for many years working on the creation of new grapevine cultivars. Until now, it has created 23 cultivars (15 for fresh consumption and 8 for wine production) [8]. Also, from the different crossing combinations has been obtained a large number of the hybrids which are investigating in relation to the purpose of selection. For each of them is study the most important agrobiological and economictechnological characteristics. After the first stage of the selection single out best genotypes that are vegetatively multiplied. They can be further examined at different locations before or during the procedure for recognition of new cultivars.

Most commercially important traits of grapevine, such as berry ripening time, berry weight, soluble solids concentration, titratable acidity, and berry flesh texture are quantitative, and fluctuate depending on environmental factors. Therefore, it is important for grape breeders to obtain information on the contribution of genetic and environmental factors to phenotypic expression [11]. Methodologies for determining genotypic stability range from conventional analysis of variance to regression analysis, as well as genetic correlations [9].

The importance of grapevine grown lies in the fact that it is one of the most humble plant species because thrives in very different ecological conditions. On the overall grape quality of some cultivar is greatly influenced by external factors such as climate, soil composition, weather conditions during the growing season, agrotechnical practices, choice of rootstock and tradition of cultivation 


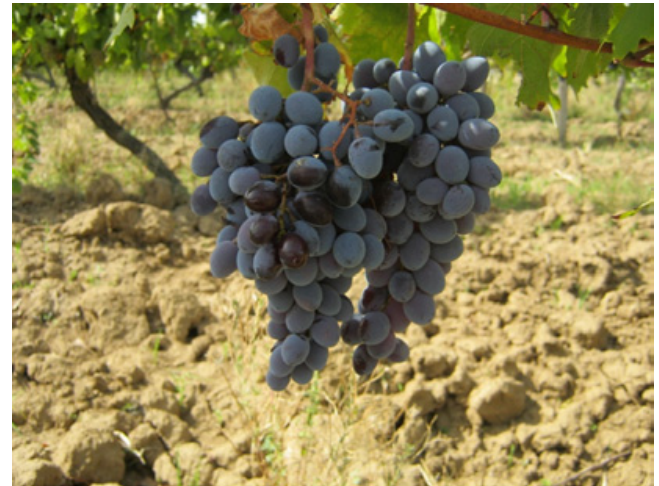

Figure 1. Hybrid 9846.

in some region. In so heterogeneous localities choice of appropriate cultivars or clones has very great importance for obtaining optimal grape quality [13].

The aim of this study was to investigate the economic and technological characteristics of four different interspecific hybrids of grapevine at two localities in Serbia.

\section{Material and methods}

\subsection{Materials}

\subsubsection{Experimental site}

The examinations were conducted in two grape growing regions: Belgrade region - Grocka vineyards and South Banat region - Vršac vineyards. Grocka vineyards located in the hilly area on the right side of the Danube, downstream from Belgrade. The vineyards are located at 496.12 ha. There dominate table cultivars, which are grown in $83.7 \%$ of the area of all the vineyards [2]. Area of Radmilovac belonging to this vineyards. Vršac vineyards has about 2,000 ha. The vineyards stretch along the southern and northern sides of the Vršac Mountains at an altitude of 50-200 m.

\subsubsection{Examined grapevine hybrids}

Four new interspecific hybrids, which are intended for table consumption: 9846, 9896, 19574 and 20506 were used as a material in this paper. All hybrids were grafted on $V$. berlandieri $\mathrm{x} V$. riparia Kober $5 \mathrm{BB}$ rootstock and planted at a distance of $3.0 \times 1.0 \mathrm{~m}$. The training system was double Guyot. Table 1 shows the hybrids and their parental partners.

Table 1. Labels and cross combinations of investigated hybrids.

\begin{tabular}{|l|l|}
\hline Hybrid & Crossing combination \\
\hline 9846 & Muscat Hamburg $\times$ SV 12375 \\
\hline 9896 & Muscat Hamburg $\times$ SV 12375 \\
\hline 19574 & SV 18315 $\times$ Muscat Hamburg \\
\hline 20506 & Seedling $113 \times$ Muscat Hamburg \\
\hline
\end{tabular}

Figures 1, 2, 3 and 4 shows the bunche appearance of investigated hybrids.

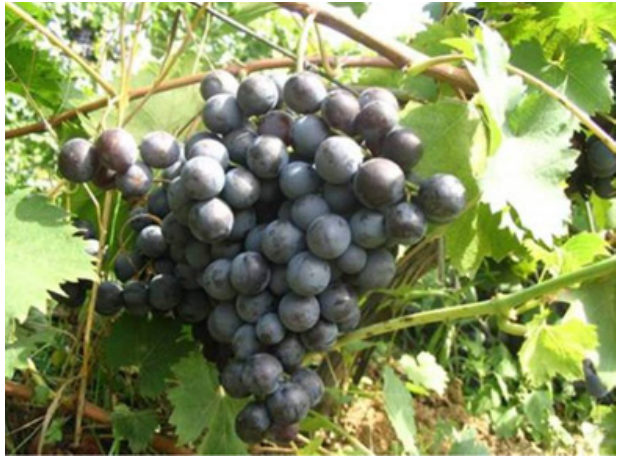

Figure 2. Hybrid 9896.

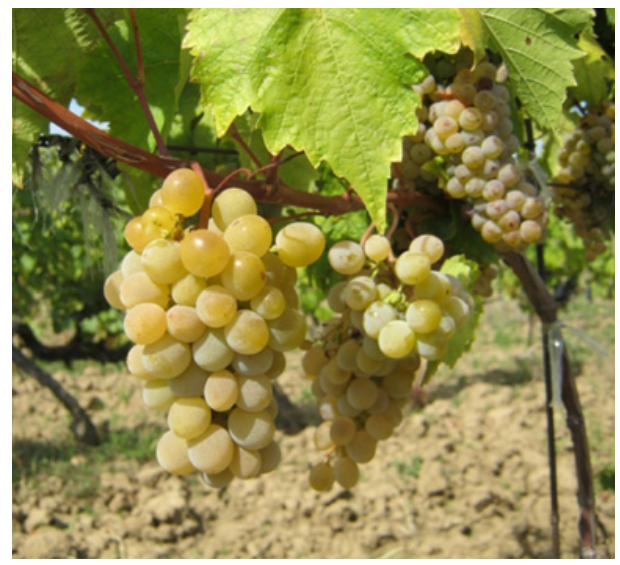

Figure 3. Hybrid 19574.

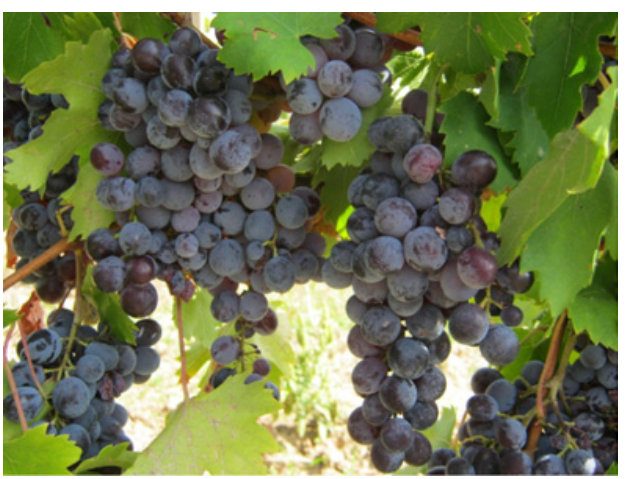

Figure 4. Hybrid 20506.

\subsection{Methods}

Grape yield per unit area, the properties of the bunch (bunch weight, bunch length, bunch width and number of berries in bunch), the properties of berry (berry weight, berry length and berry width), as well as the characteristic of grape quality (sugar content and total acids in the must) were studied in selected hybrids. Grape yield per unit area was determined by calculation, based on the total number of vines per hectare and the average grape yield per vine. The bunch weight was established by the measurement of the bunch on "CAS-Shollex type SHRE-122" scale. Length and width of bunch were determined by measuring with a ruler. Number of berries in bunch was established by counting the total number of berries in bunch. The berry weight is determined by measuring on analytical ballance "Tecator-6110 Balance". Length and width of berry were determined by caliper measurements. Sugar content in 
Table 2. Properties of the bunch of investigated hybrids in the localities Radmilovac and Vršac.

\begin{tabular}{|c|c|c|c|c|c|c|}
\hline Hybrid & \multicolumn{2}{|c|}{ Locality } & $\begin{array}{c}\text { Bunch weight } \\
\text { (g) }\end{array}$ & $\begin{array}{l}\text { Bunch length } \\
(\mathrm{cm})\end{array}$ & $\begin{array}{l}\text { Bunch width } \\
\text { (cm) }\end{array}$ & $\begin{array}{c}\text { Number of berries } \\
\text { in bunch }\end{array}$ \\
\hline \multirow{2}{*}{9846} & \multicolumn{2}{|c|}{ Radmilovac } & 239.0 & 17.8 & 11.7 & 56.6 \\
\hline & \multicolumn{2}{|c|}{ Vršac } & 222.6 & 14.2 & 10.9 & 62.4 \\
\hline \multirow{2}{*}{9896} & \multicolumn{2}{|c|}{ Radmilovac } & 262.4 & 16.6 & 11.9 & 71.2 \\
\hline & \multicolumn{2}{|c|}{ Vršac } & 270.6 & 14.6 & 11.4 & 69.8 \\
\hline \multirow{2}{*}{19574} & \multicolumn{2}{|c|}{ Radmilovac } & 185.8 & 15.9 & 9.7 & 50.0 \\
\hline & \multicolumn{2}{|c|}{ Vršac } & 169.0 & 14.8 & 9.3 & 49.4 \\
\hline \multirow{2}{*}{20506} & \multicolumn{2}{|c|}{ Radmilovac } & 217.2 & 16.5 & 11.8 & 53.0 \\
\hline & \multicolumn{2}{|c|}{ Vršac } & 192.0 & 14.7 & 10.3 & 52.6 \\
\hline \multirow{2}{*}{\multicolumn{2}{|c|}{ LSD Hybrid (H) }} & 0.005 & 25.22 & - & 1.12 & 7.0 \\
\hline & & 0.001 & 33.96 & - & 1.51 & 9.43 \\
\hline \multirow{2}{*}{\multicolumn{2}{|c|}{ LSD Locality (L) }} & 0.005 & - & 0.61 & - & - \\
\hline & & 0.001 & - & 0.82 & - & - \\
\hline \multirow{2}{*}{\multicolumn{2}{|c|}{ LSD H x L }} & 0.005 & - & 1.22 & - & - \\
\hline & & 0.001 & - & 1.65 & - & - \\
\hline
\end{tabular}

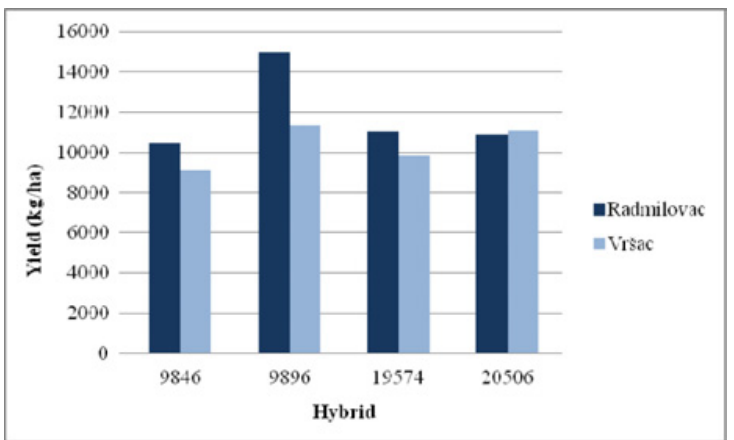

Figure 5. Grape yield per unit area of investigated hybrids in the localities Radmilovac and Vršac.

the must was established using a digital refractometer (PocketPal - 1, Atago, Japan). The total acid content in the must was determined by the method of titration with $n / 4$ $\mathrm{NaOH}$.

\subsection{Statistical analysis}

Statistical analysis was done by the method of analysis of variance (ANOVA) two-factorial design, using the $\mathrm{F}$ test at $\mathrm{P}<0.05$ and $\mathrm{P}<0.01$. In cases where the $\mathrm{F}$ test was significant, the significance of differences between mean values was determined using a LSD test for the significance level $\mathrm{P}<0.05$ and $\mathrm{P}<0.01$. Data analysis was performed using the statistical software package Statistica, Version 8 (StatSoft, Inc., Tulsa, Oklahoma, USA).

\section{Results and discussion}

On the basis of the total number of vines per unit area and the average yield of grape per vine, it was found that the highest yield per hectare had the hybrid $9896(14998 \mathrm{~kg})$ at Radmilovac, and the smallest hybrid $9846(9099 \mathrm{~kg})$ at Vršac (Fig. 5). In Serbia, [12] examining the production and technological properties of some promising grapevine seedlings at Radmilovac found that the greatest differences between genotypes were determined in the yield.

Table 2 shows the results of the mechanical analysis of the bunch at studied hybrids grown on Radmilovac and Vršac, as well as the results of statistical analysis of the parameters analyzed. The average largest bunch weight on both localities was achieved by hybrid 9896 (262.4 g; $270.6 \mathrm{~g})$, and the smallest hybrid 19574 (185.8 g; $169.0 \mathrm{~g})$. The smallest bunch length had the hybrid 19574 $(15.9 \mathrm{~cm})$, and the highest hybrid $9846(17.8 \mathrm{~cm})$ at the Radmilovac. At the locality of Vršac the smallest bunch length had the hybrid $9846(14.2 \mathrm{~cm})$, and the highest hybrid $19574(14.8 \mathrm{~cm})$. The highest bunch width and the number of berries in bunch at both localities was achieved by hybrid $9896(11.9 \mathrm{~cm} ; 11.4 \mathrm{~cm} ; 71.2$; 69.8), while the smallest bunch width and the number of berries in bunch had the hybrid $19574(9.7 \mathrm{~cm} ; 9.3 \mathrm{~cm}$; $50.0 ; 49.4)$. Analysis of variance showed significant differences between investigated hybrids for the bunch weight, bunch width and number of berries in bunch. Significant differences between studied localities and the interactions between hybrid and localities were determined only for the bunch length.

The average largest berry weight on both localities was achieved by hybrid 20506 (3.6 g, 3.1 g), while the lowest berry weight at the locality Radmilovac had the hybrid 9896 (2.9 g), and at the locality Vršac the hybrid 19574 (2.6 g). At both localities, the average largest berry length was achieved by hybrid $9846(19.7 \mathrm{~mm} ; 17.1 \mathrm{~mm})$, while the smallest berry length had the hybrid 9896 $(16.1 \mathrm{~mm})$ at the locality Radmilovac, and at locality Vršac the hybrid $19574(16.0 \mathrm{~mm})$. The average largest berry width had the hybrid $9846(16.4 \mathrm{~mm})$, and the lowest hybrid $9896(15.6 \mathrm{~mm})$ at the locality Radmilovac. At the locality Vršac, average largest berry width had the hybrid $9896(15.4 \mathrm{~mm})$, and the lowest hybrid $9846(13.0 \mathrm{~mm})$. Analysis of variance showed significant differences among the hybrids for the berry weight and berry length. Significant differences between localities were detected for all three characteristics. The interaction between hybrids and localities showed significant differences in the length and width of berry.

Significant differences between genotypes, localities and their interaction for some of bunch and berry properties are shown by [10], examining the characterization and adaptation of some Pinot Noir clones of Radmilovac and Vršac (Table 3).

The content of sugar and total acids in the must is an important factor in the quality of the grape. At the degree 


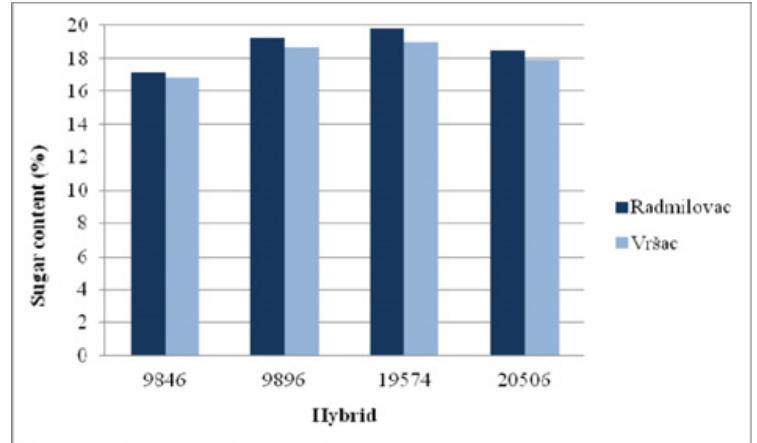

Figure 6. Sugar content in the must of investigated hybrids in the localities Radmilovac and Vršac.

Table 3. Properties of berry of investigated hybrids in the localities Radmilovac and Vršac.

\begin{tabular}{|c|c|c|c|c|c|}
\hline Hybrid & \multicolumn{2}{|c|}{ Locality } & $\begin{array}{c}\text { Berry } \\
\text { weight } \\
\text { (g) }\end{array}$ & $\begin{array}{l}\text { Berry } \\
\text { length } \\
(\mathrm{mm})\end{array}$ & $\begin{array}{l}\text { Berry } \\
\text { width } \\
(\mathrm{mm})\end{array}$ \\
\hline \multirow{2}{*}{9846} & \multicolumn{2}{|c|}{ Radmilovac } & 3.3 & 19.7 & 16.4 \\
\hline & \multicolumn{2}{|c|}{ Vršac } & 2.7 & 17.1 & 13.0 \\
\hline \multirow{2}{*}{9896} & \multicolumn{2}{|c|}{ Radmilovac } & 2.9 & 16.1 & 15.6 \\
\hline & \multicolumn{2}{|c|}{ Vršac } & 2.8 & 16.4 & 15.4 \\
\hline \multirow{2}{*}{19574} & \multicolumn{2}{|c|}{ Radmilovac } & 3.1 & 18.3 & 16.3 \\
\hline & \multicolumn{2}{|c|}{ Vršac } & 2.6 & 16.0 & 14.0 \\
\hline \multirow{2}{*}{20506} & \multicolumn{2}{|c|}{ Radmilovac } & 3.6 & 18.0 & 16.3 \\
\hline & \multicolumn{2}{|c|}{ Vršac } & 3.1 & 16.6 & 14.7 \\
\hline \multirow{2}{*}{\multicolumn{2}{|c|}{ LSD Hybrid $(\mathrm{H})$}} & 0.005 & 0.39 & 0.75 & - \\
\hline & & 0.001 & 0.52 & 1.02 & _- \\
\hline \multirow{2}{*}{\multicolumn{2}{|c|}{ LSD Locality (L) }} & 0.005 & 0.28 & 0.53 & 0.77 \\
\hline & & 0.001 & 0.38 & 0.71 & 1.04 \\
\hline \multirow{2}{*}{\multicolumn{2}{|c|}{ LSD H x L }} & 0.005 & - & 1.08 & 1.51 \\
\hline & & 0.001 & _- & 1.46 & 2.03 \\
\hline
\end{tabular}

of sweetness of grape juice influences the content and ratio of the amount of acids and sugars. The high sugar content and a high acids content is advantageous of ratio. Too low acidity adversely affects the taste, and therefore the quality of the grape [3].

At both localities the largest sugar content in must had the hybrid $19574(19.8 \% ; 19.0 \%)$, and the smallest hybrid 9846 (17.1\%; 16.8\%) (Figure 6). Nikolić [6], examining of interspecific hybrids at the locality Radmilovac also was determined the largest sugar content in hybrid 19574 $(21.2 \%)$. The highest content of the total acids in the must at the locality Radmilovac had the hybrid 9846 (7.1 g/l), and at the locality Vršac hybrid 19574 (6.9 g/l). Based on Figure 7 it can be seen that at both localities, the smallest total acids content in the must had the hybrid 9896 (6.3 g/l; $6.1 \mathrm{~g} / 1)$.

\section{Conclusions}

Based on examination of four different hybrids (9846, 9896, 19574 and 20506) which have been grown on two different localities (Radmilovac and Vršac) the following can be concluded:

- For most of the studied traits were determined the differences between investigated hybrids and between investigated localities.

- The hybrid 9896 had the highest yield per hectare and the largest bunch weight at both localities.

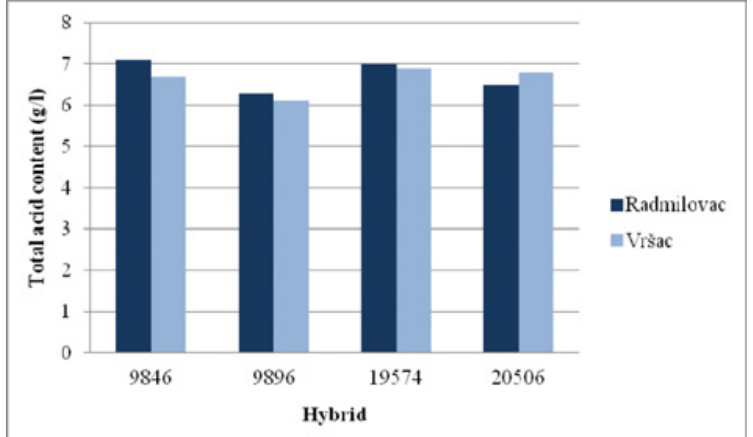

Figure 7. Total acids in the must of investigated hybrids in the localities Radmilovac and Vršac.

- The average largest berry weight had the hybrid 20506 at both localities, and the smallest hybrid 19574 from locality of Vršac.

- The highest sugar content had the hybrid 19574, and the lowest hybrid 9846 at both localities.

- The highest content of total acids in the must had the hybrid 9846 from the locality Radmilovac, and the smallest hybrid 9896 from both localities.

- Hybrid 9896 showed the best characteristics at both localities and is considered to be the most promising hybrid for the introduction of further production.

Ths study was supported by and Ministry of Education, Science and Technological Development of the Republic of Serbia, Project TR 31063.

\section{References}

[1] Gray, D.J., Li, Z.T., Dhekney, S.A. Precision breeding of grapevine (Vitis vinifera $\mathrm{L}$.) for improved traits. Plant Sci. 228, 3-10 (2014)

[2] Ivanišević, D., Jakšić, D., Korać, N. Popis poljoprivrede 2012. Poljoprivreda u Republici Srbiji. Vinogradarski atlas. Republički zavod za statistiku, Beograd (2015)

[3] Liu, H.F., Wu, B.H., Fan, P.G., Xu, H.Y., Li, S.H. Inheritance of sugars and acids in berries of grape (Vitis vinifera L.). Euphytica 153(1), 99-107 (2007)

[4] Maletić, E., Karoglan-Kontić, J., Pejić, I., Preiner, D., Zdunić, G. Bubola, M., Stupić, D. Andabaka, Ž., Marković, Z., Šimon, S., ŽuljMihaljević, M., Ilijaš, I., Marković, D. Zelena knjiga: Hrvatske izvorne sorte vinove loze. Državni zavod za zaštitu prirode, Zagreb (2015)

[5] Nikolić, D. Oplemenjivanje vinove loze. Monografija, Fleš, Zemun (2012)

[6] Nikolić, D. Properties of two interspecies grapevine hybrids from Serbia. Acta Hortic. 1082, 141-147 (2015)

[7] Nikolić, D., Milutinović, M., Rakonjac, V., Fotirić, M. Evaluation of resistance to low temperatures in promising interspecies grapevine hybrids. Acta Hortic. 827, 461-464 (2009)

[8] Nikolić, D., Ranković-Vasić, Z., Atanacković, Z. New Serbian grapevine genotypes for red wine production. Vitis 54, 165-168 (2015)

[9] Onokpise, O.U., Mortensen, A. Genotype x environment interaction in Vitis rotundifolia Michaux. Am. J. Enol. Vitic. 39(2), 121-124 (1988) 
[10] Ranković-Vasić, Z, Nikolić, D., Atanacković, Z., Sivčev, B., Ruml, M. Characterization and adaptation of some 'Pinot Noir' clones to the environmental conditions of Serbian grape growing regions. Vitis 54, 147-149 (2015)

[11] Sato, A., Yamada, M., Iwanami, H., Hirakawa, N. Optimal spatial and temporal measurement repetition for reducing environmental variation of berry traits in grape breeding. Sci. Hort. 85(1-2), 75-83 (2000)

[12] Sivčev, B., Žunić, D., Jović, S. Productiontechnological characteristics of some promising grapevine seedlings in the condition of experimental station "Radmilovac". J. Agric. Sci. 45(2), 93-99 (2000)

[13] Sivčev, B., Ruml, M., Sivčev, I., Ranković-Vasić, Z. Organska proizvodnja grožđ a. Monografija, Poljoprivredni fakultet, Beograd (2015)

[14] This, P., Lacombe, T., Thomas, M.R. Historical origins and genetic diversity of wine grapes. Trends Genet. 22(9), 511-519 (2006)

[15] Viana, A.P., Riaz, S., Walker, M.A. Evaluating genetic diversity and optimizing parental selections in a segregating table-grape population. Am. J. Enol. Vitic. 62(3), 285-290 (2011) 